\title{
The Importance and Usage of National Census for Security and Development of Nigeria
}

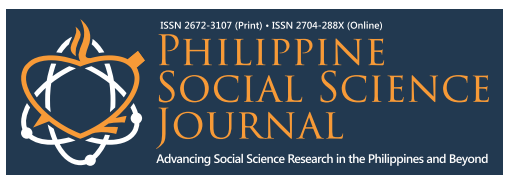

Babatope Matthew Ajiboye

Department of Peace and Conflict Studies, Federal University Oye-Ekiti, Ekiti State, Nigeria

\section{Article history:}

Submitted: 8 October 2021

Revised: 10 December 2021

Accepted: 21 December 2021

Keywords:
National census
Security
Development
Nigeria

ABSTRACT. Census exercise is based on the notion that clear-cut data is at the center of a roadmap that enables planning, implementation, and long-term development. Because these objectives were not met, most census research in Nigeria has focused on the difficulties, problems, and politics underlying the falsification of census results. Surprisingly, none has articulated why a census is required for security and development. As a departure from the contentious debate enveloping the population, the paper examines the indices census has on the security and development of Nigeria. The cross-sectional survey design was adopted for the study using the proportionate stratified sampling in selecting 270 respondents that cut across three towns: Ado, Ikere, and Ikole, representing each senatorial district of Ekiti State. The questionnaire served as the instrument for data collection. Findings revealed mixed perceptions about the use of census for tackling security challenges, infrastructural planning and developmental stride.

\subsection{Introduction}

The rationale behind conducting censuses at regular intervals in most societies is to ensure better performance in terms of planning sustainable development that is not limited to the socio-economic sector alone but also extended to other sectors for faster attainment of holistic development. For Ashkpour (2019), censuses contain a wealth of information about nations and societies. They structurally capture societal information needs at given times in the past. Throughout history, the censuses have served to provide information to governments to understand the development of the nation and its population on several fronts for decision-making purposes. For instance, in the United States, Reamer (2018) noted that topical research indicates census-obtained data were used to allocate more than $\$ 850$ billion to states and localities through 302 programs in Fiscal Year 2016 alone. Similarly, Mohammed et al. (2019, p. 16) observed that:

Over time and from pre-independence to date, several heads and housing counts have been conducted to obtain the total number of persons in Nigeria over given periods. Those were particularly important as no meaningful planning and development could be made and successfully implemented without knowing who and how many to plan for, what to plan, and at what time? Without these, no sustainable development can be achieved. As such, a national census policy presents basic information on a country's population that enables seamless government planning and policy implementation that underscores all-around national development.

This importance informed the Nigerian government to establish the Nigeria Population Commission (NPC) (1988), domiciled under the Federal Ministry of Interior with the statutory powers to collect, analyze and disseminate demographic data in the country. Its other duties include undertaking demographic sample surveys, compiling, collating, publishing migration and civil registration statistics, and monitoring the country's population policy. Therefore, it is deducible that the Commission superintends everything that hovers on human and housing populations and sustainable development of the nation. The relevance of census to planning, implementation, and execution of public initiatives which performance is mirrored through critical sectors such as economy, security, and sustainable development of any nation, has been stressed by United Nations as follows:

The population and housing census is critical in public management. The results of a census are used as a critical reference to ensure equity in the distribution of wealth, government services, and representation throughout the country, for example, by informing the distribution and allocation of government funds among various regions and districts for education and health services, delineating

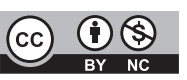

This article published by Philippine Social Science Journal (PSSJ) is licensed under a Creative Commons AttributionNoncommercial 4.0 International (CC BY-NC 4.0). You are free to share (copy and redistribute the material in any medium or format) and adapt (remix, transform, and build upon the material). Under the following terms, you must give appropriate credit, provide a link to the license, and indicate if changes were made. You may do so in any reasonable manner, but not in any way that suggests the licensor endorses you or your use. You may not use the material for commercial purposes. 
electoral districts at the national and local levels, and measuring the impact of industrial development, to name a few (United Nations, 2017, p. 1).

Expanding census relevancy to a multipurpose usage, Egeler et al. (2013, p. 396) argued that "the usability of the results has become much more varied. It ranges from policy issues and economic aspects to social themes. In the statistical field, too, census results are used in manifold ways". However, a question that any sane government must first answer before embarking on tactics aimed at cushioning these acts and also implementing developmental infrastructure that has to do with people is to sincerely identify the number of people inhabiting the surface of the country at a regular interval as this would help in determining who gets what, when and why in the country's arrangement. However, if after more than fourteen years Nigerian government still largely depend on the festering 2006 census as if it has the whole country under its feet and becomes obligatory for the figures therein to be constantly used in piloting policies, programs, and implementation, then, it does appear the government has finally given up on providing a convincing answer to the question of how many are we? Again, it is not surprising that the outcomes of the dependency on the old-fashioned 2006 census figures have not been anything different from disappointment because those policies and initiatives have been outshined by the dwarfed socio-economic realities and gross security challenges such as incessant banditry, Boko Haram insurgency, ceaseless farmers/herders clashes, festering cattle rustling, constant kidnapping, and other issues increasingly threatening safety and survival of the nation.

Although there have been population exercises conducted in the past aimed at ascertaining the country's population, upsettingly, it has remained a utopia. On each occasion, it has always ended in one controversy or the other. According to Akanni (2020), all previous attempts in Nigeria to conduct population and housing censuses have been hampered by difficulties. These have ranged from a lack of staff and logistics to unjustified political involvement and manipulation. As a result, there have been conflicts and disagreements. The 2006 national census was the final in a long line of censuses and disputes. Figures recorded in the exercise could not be trusted because sharp practices weakened and increased the number geometrically beyond what the country would have become in two more decades. Indeed, it is not surprising that issues were to blame for the fake and over-blotted results announced at the end of the exercise. The multiplicity of Nigerian society is an excellent example since each area was wary of being controlled or marginalized in the grand scheme of things. Stallings (2006) argued that the elite are frequently over-zealous about the worth and importance of population census. They always do everything to enumerate all their people and engage in other illegalities: electoral violence, falsification, and manipulation of population data validating what orchestrated the outrageous figures of censuses in Nigeria.

Eme (2015) equally argued that census politics in Nigeria is conterminous to petty-bourgeois politics. It refers to the struggle amongst states and/ or ethnic nationalities towards the inflation of census figures to their selfish advantage. This position has further been re-echoed by Serra and Jerven (2021) when they opined that anomaly accompanied census figures in Nigeria result from the importance of population returns for federal parliamentary representation and the allocation of federal revenues and social services. It is not surprising that Nigerian census results have been hotly contested. A decade and a half down the lane, the question glued on everyone's lip is, how many are we? The unsurpassed answer to the unanswered question remains rooted in the dictum; 'your guess is as good as mine'. Part of these quagmires stems from the fact that the nation has not organized and conducted census exercises for nearly two decades running. Conversely, an eyebrow has not been further raised as to why Nigeria as a nation keeps begging and guessing for an answer whenever the question of the precise population of the country gets raised even in the 21st century. This is due to the contestable figures released in 2006 by the National Population Commission (NPC), that pegged Nigeria's population at $140,431,790$ and also the failure of successive governments to conduct credible census since 2006, has further boosted everyone's speculation and thickened the debate as per the actual number of people in the country not leaving out the academics, researchers and content developers off the guess desk.

Nevertheless, as far as census-related issues are concerned, there are arrays of literature written on them. Interestingly, most of the scholarly inquiries have explicitly espoused population, housing, statistics, and sustainable development; others have discussed issues hanging around population figures, such as falsification, quota politics, problems and prospects, patterns of population distribution, and administrative census as an alternative to the conventional headcount system. Writing in support 
of census as the elemental conceived and most reliable form of researching that others strive to emulate, Golata (2014) stressed that a population census is not only the oldest research, best-known, well-formed in terms of methodology but also research, which is widely regarded as the most reliable data source. Ogunlade (2000) listed the usefulness of census to include the determination of the handicapped for the provision of basic social amenities and also for ascertaining the actual figure of the unemployed to make for adequate planning... other purposes according to him are: number of school children, measurement of development, the standard of living, delimitation of constituencies, population density and the determination of migration rate. In a move to outsmart one another and subvert the advantage to one's side, there has been a pattern of falsification in the censuses conducted years back. Adele (2009), in his article, documented the controversy surrounding the population census in Nigeria that took place between March 21 and 25, 2006.

Beyond this, the definition of census appeals to our attention. The Department of Economic and Social Affairs of the United Nations defined a population census as the total process of planning, collecting, compiling, evaluating, disseminating, and analyzing demographic, economic, and social data at the smallest geographic level pertaining, at a specified time, to all persons in a country or a well-delimited part of a country (United Nations, 2017). By this definition, it has been shown that census is not a walk in the park. Therefore, it is a detailed sequence that every stage remains significant as any omission may make or mar the whole exercise. Equally, it has been pointed out that it must be intervallic (advisably ten years) to accommodate dynamism in variables as adopting old data for current planning would mean stunted results in terms of development. To further boost our understanding of the variants of the census, it is therefore narrowed to the housing. It is defined as the total process of planning, collecting, compiling, evaluating, disseminating, and analyzing statistical data relating to the number and condition of housing units and facilities as available to the households pertaining, at a specified time, to all living quarters and occupants thereof in a country or a well-delimited part of a country (United Nations, 2017). However, combining the two descriptions within the context of the census, the United Nations defined census as an operation that produces an official count of a country's population, right down to the lowest level of geographical detail, at regular intervals (United Nations Economic Commission for Europe [UNECE], 2006).

Shifting attention away from the definition of a census to the strategic relevance or indispensability of census to issues of policy, socio-economic and other social aspects, census importance on a wide range of decisions that affect humanity has been described as sin qua non in the communiqué of the United Nations (United Nations, 2017, p. 1), "establishing a public consensus on priorities would be almost impossible to achieve if it were not built on census counts". Therefore, it is observable that development is indispensable to planning which is rooted in accurate census figures, while development has to do with a tactical change in security architecture, sustainable development, and advancement of various human aspects needed to achieve desired progress, every country's safety is determined by its development which is attached to the reliability of census module obtained in the country. Still, in the doldrums of the exact population becoming insatiable for the country, the Chairman of National Population Census (NPC), Nasir Kwarra, maintained that in the absence of an actual census, we formally make projections, and we estimate that as of 2020, the estimated population of Nigeria is 206 million (Sahara Reporters, 2020). With the recent declaration by the Chairman National Population Commission (NPC), Nasir Kwarra, the nation does not seem to be in a hurry to answer the puzzle of 'how many are we? It is evident in the speech of the NPC boss, as he categorically affirmed that as a country, we are not going to conduct a census this year (Ochayi, 2021).

Nigeria's policy and strategic mechanisms as regard exact population of the country which can readily be an operational modus when it comes to planning and implementation of societal transformational initiatives to enhance socio-economic activities, political stability, robust security network, and a facelift of infrastructural development of the nation has been hampered and hindered by the continued utilization of the defective, outdated and fly-by-night census figures of 2006. As such, various government policies, strategies, and programs having direct implications on the country's population have failed to measure up with the current realities of the day. The failures have been amplified and replicated in the critical sectors of the country. For instance, security which is the umbilical cord shaping the existence of other important sectors, has not been adequately taken care of due to the inconsistency with data available for tackling challenges: kidnapping, human trafficking, cattle rustling, banditry, and other terrorism-related activities. Following this lapse, machinery has to be set in motion at conducting census at intervals to improve the security and 
development of the nation. Besides, every idea that seeks to transform a nation hangs and hinges on a dependable census. As enshrined in the words of Harper and Mayhew (2012), that it was possible to replicate local census enumeration, and there are yet again many other data sources available to academics. However, national coherence can only be found in the census. As a response, the paper examined, amongst other things, the importance and usage of the national census for the security and development of Nigeria.

Thus, the study's main aim is to examine how national census policy can meaningfully translate to improvement in the security and development of the nation. Specifically, it aimed to elicit and show the importance of census on the security and development of the nation; and reveal the level and extent of census data usage while strategically implementing the security architecture and execution of infrastructural development of the nation.

\subsection{Framework of the Study}

The study has a theoretical grounding on Structural Functionalism Theory (SFT). Structural functionalism, as a sociological theory, lacks a single, coherent, and consistent theorist. Different writers emphasize different things, and they use distinct terminology and incorporate different phenomena under a range of similar words in their explanation of the theory (Hudson, 1978). Herbert Spencer, Emile Durkheim, Bronislaw Malinowski, Alfred Radcliff-Brown, and Robert K. Merton were among the theory's early proponents. The structural-functionalism hypothesis was characterized by the triad of Parsons, Merton, and Durkheim as each civilization gets concerned with collective object build-up with components and pieces that the entire society controls on for survival. As a result, if any component fails to give equal service that supplies equality between each component source, the repercussions are frequently dysfunctional, jeopardizing the whole society's safety (Hustedde \& Ganowicz, 2002). However, Talcott Parsons, an American sociologist, was the most renowned among the proponents whose work inspired the theory and provided clarity in terms of the workings, structure, and compartmentalization of society and institutions in relation to functions and roles. He once argued that stable structural categories comprise a civilization's interrelated systems and serve to sustain society.

The notion of structural functionalism is based on two premises: structural breakdown and functional clarifications. The term structural breakdown refers to how society is viewed through the prism of describing roles, connections, and institutions. Similarly, social processes must be comprehended at the level of institutional manifestation rather than described by summarizing individual acts and dispositions. According to Akubue and Okolo (2014), the structure of society may be analyzed via the lens of its subsystems. The construal reality of the preceding premise is that society is made up of mutually interconnected or interlinked systems, with each component allocated a certain role to play in society. Per the functionalists, institutions' existence, duration, and structure may be explained in terms of their contribution to societal stability. The analysis focuses on organizations and society rather than individuals. All societies must perform certain tasks and meet specific imperatives in order to continue to exist as cohesive societies; the term "societal requirements and requisites" describes the functional approach (Turner \& Maryanski, 1988). Functionalism holds that the existence, durability, and shape of institutions may be explained in terms of their contribution to societal stability. To continue to exist as cohesive societies, all societies must complete particular tasks, satisfy specified imperatives; the term "societal requirements and requisites" summarizes the functional approach (Turner \& Maryanski, 1988). The contribution of these experts in identifying the role of components, units, and fragments and the functions of census data in planning for peace, security, and development in every clime unquestionably demonstrates its relevance as top-notch.

The point of convergence with the subject at hand is that society is made up of components (individualism) that aggregate to make the whole (holism). In line with structural functionalism theory, the Nigerian Population Commission (NPC) (a societal body) is at the center of any study concerning population and housing census management. In other words, the commission is shown as one of the structural functionalism theory's components. Society relies on to determine valid and dependable census data from various parts and backgrounds of the country. Moreover, to adequately plan for the individuals who make up society, effectively carry out cross-cutting development, and provide robust security that can ensure 21st Century safety, the national census, therefore, becomes a conduit or vehicle for realizing this functionality. In retrospect, censuses serve as a bridge between social objectives and their implementation, which transform into apt realities. 


\subsection{Methods}

For the study, a cross-sectional survey approach was used. A cross-sectional survey collects data to conclude a population of interest at a certain point in time (Lavrakas, 2008). The approach was chosen because it allowed for a subset of the population to be interviewed. The informative data gained from them represented the whole population in the research. The research was carried out in the Nigerian state of Ekiti, located in the country's south-western region. Three towns (Ado, Ikere, and Ikole) were purposefully chosen to reflect each state's senatorial districts. The towns were chosen with care since they are the largest towns in each state's senate district. Ekiti state was one of six states established on October 1, 1996, by the previous military head of state, Late General Sanni Abacha. Prior to the separation in 1996, the state was a component of the old Ondo State. The state is blessed with human resources and agriculturally friendly vegetation, which invariably keeps the majority of its inhabitants employed with farming.

Farmers, public officials, politicians, and adolescents aged 18 and up were among those who took part in the survey. The quota random sample approach was employed to pick respondents from various cadres for the study. A large questionnaire was used to collect data for the investigation. The study, on the other hand, used a combination of quantitative and qualitative data gathering approaches. The quantitative data was mostly gathered through the use of a self-administered questionnaire provided to respondents. And the qualitative data used in the study was obtained through an in-depth interview with some randomly chosen members of the public. The main reason for this selection was that these individuals possessed the necessary ideas and enthusiasm for the subject under consideration. The quantitative data was examined using a basic percentage and frequency distribution table, while the qualitative data was studied using content analysis and verbatim quotations from research participants, which added value and aphorism to the study. However, it is vital to clarify that the names of respondents in the study are safeguarded as part of the ethical considerations that this study held in high regard.

\subsection{Results and Discussion}

The demographic characteristics of respondents are represented in Table 1 below. The gender distribution indicated that 182 deciphering 67.4 percent of respondents were males, while 88 representing 32.6 percent were females. The indication of this is that males with $67.4 \%$, dominated the bulk of respondents.

Table 1. Demographic characteristics of respondents

\begin{tabular}{lcc}
\hline Demographics & $\mathrm{f}$ & $\%$ \\
\hline Gender & 182 & 67.4 \\
Males & 88 & 32.6 \\
Females & 270 & 100 \\
Total & & \\
Age Groups & 185 & 68.5 \\
18-40 & 57 & 21.1 \\
$41-60$ & 28 & 10.4 \\
60 and above years & 270 & 100 \\
Total & & \\
Education Qualifications & 29 & 10.7 \\
Trade \& Vocational Training & 20 & 7.4 \\
Primary & 65 & 24.1 \\
Secondary & 156 & 57.8 \\
Tertiary & 270 & 100 \\
Total & & \\
Employment Status & 71 & 26.3 \\
Student & 118 & 43.7 \\
Unemployed & 53 & 19.6 \\
Employed & 28 & 10.4 \\
Retired & 270 & 100 \\
Total & &
\end{tabular}


The respondents' age distribution showed that 185 equaling 68.5 percent were between the ages of 18-40, 57 representing 21.1 percent were within the age range of 41-60, while 28 translating 10.4 percent were 60 years and above. The import of this analysis is that the majority of the respondents, $68.5 \%$, fall within the age group of $18-40$.

The respondents' educational qualifications show that 29 , implying 10.7 percent have a trade and vocational training certificate, 20 representing 7.4 percent of the respondents possess a primary school leaving certificate and 65 equaling 24.1 percent of the respondents have secondary education, while 156 deciphering 57.8 percent have tertiary education. The translation of this is that the majority $(57.8 \%)$ of the respondents attained tertiary education.

The respondents' employment status shows that 71 deciphering 26.3 percent were students, 118 indicating 43.7 percent were unemployed, and 53 implying 19.6 percent of the respondents are employed, while 28 representing 10.4 percent of the respondents are retirees. This means that the majority of the respondents with $43.7 \%$, are unemployed.

\title{
Importance of Census
}

Table 2 underneath indicates that 77 of the respondents translating 28.5 percent observed that census has very large importance in ensuring robust security and development of the nation, 125 of the respondents representing 46.3, were of the thought that security and development of the nation rest largely on census template and 49 of the respondents translating 18.2 percent think census has little importance on the robust security and development of the nation. However, 19 of the respondents signifying 7.0 percent, believed that census has no importance on robust security and development of the nation. On the importance of the census, here is a respondent's reaction:

\begin{abstract}
The census exercise is critical not only for security but for all sectors of the country. Can you think of any industry that does not require an accurate census blueprint for planning? If your response to my query is unenthusiastic, it is a necessary motivator for development and an economic evaluation of equal infrastructure distributed across the board. When this is completed, we will achieve the meaningful and unrestricted progress that we all seek in the twenty-first century. IDI/M/Lawyer/2021.
\end{abstract}

Table 2. Importance of censu s as template for robust security and development of the nation

\begin{tabular}{lll}
\hline Responses & $\mathrm{f}$ & $\%$ \\
\hline Very large importance & 77 & 28.5 \\
Large importance & 125 & 46.3 \\
Little importance & 49 & 18.2 \\
No importance & 19 & 7.0 \\
Total & 270 & 100 \\
\hline
\end{tabular}

Table 3 beneath shows that 131 of the respondents representing 48.5 percent, noted that the incredible census had done a very large impairment to the security, and development of the nation, 92 of the respondents translating 34.1 percent, held the view that failure of the credible census has done large impairment to the security and development of the nation, and 33 of the respondents indicating 12.2 percent opined that failure of the credible census had done little impairment to the security and development of the nation, while 14 of the respondents deciphering 5.2 percent observed that the failure of the credible census had not done any impairment to the security and development of the nation. A respondent quips does:

In my opinion, the majority of the difficulties emerging in truncated peace and insecurity that have not been alleviated despite reactions from security authorities have been caused by insufficient people tracking the unknown population. In other words, if we can conduct a true census of the country, the government would be aware that there is a need for the ratio of security officers to be proportionate to the nation's population. IDI/M/Civil Servant/2021. 
Table 3. Responses about degree of impairment Due to incredible census

\begin{tabular}{lcc}
\hline Responses & $f$ & $\%$ \\
\hline Very large impairment & 131 & 48.5 \\
Large impairment & 92 & 34.1 \\
Little impairment & 33 & 12.2 \\
No impairment & 14 & 5.2 \\
Total & 270 & 100 \\
\hline
\end{tabular}

Table 4 below indicates that 88 of the respondents representing 32.6 percent, held the view that for continuous improvement in security and development of the nation, periodic census exercise is a very large requirement, 152 of the respondents deciphering 56.3 percent said periodic census exercise is a large requirement for continuous improvement in security and development of the nation and 24 of the respondents equaling 8.9 percent observed that periodic census exercise is of little requirement in terms of yardstick for the continuous improvement of security and development of the nation, while 6 of the respondents indicating 2.2 percent upheld the view that periodic census exercise is of no requirement as a yardstick for the continuous improvement of security and development of the nation.

Table 4. Responses if periodic census exercise is a requirement in development

\begin{tabular}{lcc}
\hline Responses & $f$ & $\%$ \\
\hline Very large requirement & 88 & 32.6 \\
Large requirement & 152 & 56.3 \\
Little requirement & 24 & 8.9 \\
No requirement & 6 & 2.2 \\
Total & 270 & 100 \\
\hline
\end{tabular}

\title{
Extent of Census Data Usage
}

Table 5 illustrates that 17 of the respondents translating 6.3 percent noted that a very large consideration is given to census data by the government while preparing the annual budget of the security sector and infrastructural development of the nation, 41 of the respondents representing 15.2 percent, observed that a large consideration is given to census data by the government while preparing the annual budget of the security sector and infrastructural development of the nation and 130 of the respondents indicating 48.1 percent held the opinion that in preparation of annual budget of the security sector and infrastructural development of the nation, census data is given little consideration by the government, while 82 of the respondents equaling 30.4 held the view that no consideration is given to census data by the government while preparing the annual budget of the security sector and infrastructural development of the nation. A respondent cleverly remarks thus:

\begin{abstract}
Normally, this should be the most important factor to consider while creating the nation's yearly budget. But the 'holocausts' we have in charge are more concerned with how much money will enter their wallets than what would benefit the nation as a whole. That is to say, and these concerns are never prioritized while developing the annual budget. IDI/M/ Civil Servant/2021.
\end{abstract}

Table 5. Responses if government apply census data while preparing the annual budget

\begin{tabular}{lcc}
\hline Responses & $\mathrm{f}$ & $\%$ \\
\hline Very large consideration & 17 & 6.3 \\
Large consideration & 41 & 15.2 \\
Little consideration & 130 & 48.1 \\
No consideration & 82 & 30.4 \\
Total & 270 & 100 \\
\hline
\end{tabular}


Table 6 underneath illustrates that 26 of the respondents deciphering 9.6 percent, believed that to a very large extent, the nation's security and developmental policies depend on census data, 63 of the respondents translating 23.3 percent said to a large extent, the nation's security and developmental policies depend on census data and 122 of the respondents deciphering 45.2 percent believed that to a little extent, the nation's security and developmental policies depend on census data, while 59 of the respondents equaling 21.9 percent believed that the nation's security and developmental policies do not depend on census data. On policymakers using census data in formulating policies, one respondent has this to say:

The majority of these policies are implemented clumsily and hence fail to have a good influence on residents. Ours has been likened to erecting a castle in the sky. Policies are never adapted to handle any issue since the actual number of people is never considered, which is not unexpected. People's well-being has never been a primary concern for politicians. IDI/F/Student/2021.

Table 6. Responses on the nation's developmental policies depend ency on census data

\begin{tabular}{lcc}
\hline Responses & $f$ & $\%$ \\
\hline Very large extent & 26 & 9.6 \\
Large extent & 63 & 23.3 \\
Little extent & 122 & 45.2 \\
No extent & 59 & 21.9 \\
Total & 270 & 100 \\
\hline
\end{tabular}

Table 7 below signifies that 11 of the respondents translating 4.0 percent noted that very large degree, the security agencies use census data in carrying out geo-surveillance in the country, 24 of the respondents deciphering 8.9 percent believed that to a large degree, the security agencies use census data in carrying out geo-surveillance in the country and 140 of the respondents indicating 51.9 percent noted that census data is of little degree for security agencies in carrying out geosurveillance in the country, while 95 of the respondents representing 35.2 percent held the view that census data is of no degree for security agencies in carrying out geo-surveillance in the country.

Table 7. Responses on if security agencies use census data for Geo-surveillance

\begin{tabular}{lcc}
\hline Responses & $\mathrm{f}$ & $\%$ \\
\hline Very large degree & 11 & 4.0 \\
Large degree & 24 & 8.9 \\
Little degree & 140 & 51.9 \\
No degree & 95 & 35.2 \\
Total & 270 & 100 \\
\hline
\end{tabular}

Through the lens of structural functionalism theory, it is observed that NPC and census data, like the egg that metamorphoses to produce chicken, are so significant in this study. According to the majority of respondents in this study, the NPC, as the pillar or structure as the case may be, deserves serious strengthening or attention from the government that will make the commission a battleready outlet to conduct census exercises whenever the need arose. This advice was derived and subsequently became necessary because the country has been stalling conducting head and housing counts for so long. Again, census data, which is more or less the end product of this major societal component, does not require any additional explanation beyond the observations of the respondents in this study. Respondents in the study stated that the census plays a significant role in determining the success of every sector in the country. This significance was demonstrated when the majority of respondents posited that the country's incredible census had pushed most sectors backward in terms of progress. Similarly, most respondents observed that census usage had been demoted to an ancillary role in terms of application. So far, both the NPC as a structure and census data as a function of peace, security, and development has been hampered by successive governments' lip service, resulting in a poor showing of the nation's security and development. 


\subsection{Conclusion}

Since the study's sample size was just a percentage and sparse population in three communities in Ekiti State, the study's extrapolation must be done with extreme caution. Future research in this area should encompass various communities within and beyond the state to accommodate ideas and opinions from different regions of the country, which is equivalent to fairness, geographical representation, and ample generalization. Nonetheless, the study concludes that the country's prolonged impoverished developmental outcomes and vain security architecture have been exacerbated by the country's terrible national census strategy. The lopsidedness in responsibility explains the noticeable gap since the last census, which is approaching double the usual term proposed by the United Nations, ten years apart (decennial). With the country's incapacity to match her census strategy with the time supported by the World's organization, the United Nations, one cannot deny that the country has delayed far too long for another census exercise to take place. This failure has resulted in more regress than advancement in the nation's multi-circular sectors.

\subsection{Recommendations}

Based on the thoughts provided by respondents in this study, the following are developed and weighed as handy recommendations:

After too many years of doldrums and moratoriums, the census exercise has become an emergency issue requiring the government to organize another round of population and housing censuses liberally done with genuine intent to ascertain the exact number of people and housing units in the country.

The Nigerian government must imbibe and practice the minimum standard of a period in conducting census exercises advocated by the United Nations, which is a decennial (10-year period) population and housing census that is critical and central to the evolution and optimal performance of Nigeria's socio-economic, political, security and sustainable development. Because both population and housing units are constantly changing factors, requiring frequent census hounding to accommodate updates and modifications.

\section{REFERENCES}

Adele, J. (2009). Falsification of population census data in a heterogeneous Nigerian state: The fourth republic example. African Journal of Political science and International relations, 3(8), 311-319. https://doi. org/10.5897/AJPSIR.9000046

Akanni, I.A. (2020 December 10). Nigeria's census has always been tricky: Why this must change. The Conversation. https://theconversation.com

Ashkpour, A. (2019). Theory and practice of historical census data harmonization: The Dutch historical census use case: A flexible, structured and accountable approach using linked data technology.

Blumer, H. (1969). Symbolic interactionism (Vol. 50). Englewood Cliffs, NJ: Prentice-Hall.

Egeler, R., Dinsenbacher, N., \& Kleber, B. (2013). The relevance of census results for a modern society. JahrbücherfürNationalökonomie und Statistik, 233(3), 389-405.https://doi.org/10.1515/ jbnst-2013-0307

Eme, O. I. (2015). Census politics in Nigeria: An examination of 2006 population census. Journal of Policy and Development Studies, 9(3), 47-72. http://doi.org/10.12816/0011166

Gołata, E. (2014). New paradigm in statistics and population census quality. In European conference on quality in official statistics.

Harper, G., \& Mayhew, L. (2012). Using administrative data to count local populations. Applied Spatial Analysis and Policy, 5(2), 97-122.

Hudson, J. (1978) "Structural Functional Theory, Social Work Practice and Education," The Journal of Sociology \& Social Welfare, vol. 5, iss. 4, Article 4, pp.481-497.

Hustedde, R. J., \& Ganowicz, J. (2002). The basics: what's essential about theory for communitydevelopment practice? Journal of the Community Development, vol. 33, no.1, 1-19.

Lavrakas, P. J. (2008). Encyclopedia of survey research methods. Sage publications.

Maines, D. R. (1977). Social organization and social structure in symbolic interactionist thought. Annual review of sociology, 3(1), 235-259. https://doi.org/10.1146/annurev.so.03.080177.001315

Mead, G. H. (1934). Mind, self, and society (Vol. 111). University of Chicago Press. Chicago.

Mohammed, I. S., Othman, M. F., \& Osman, N. (2019). Nigerian national population and housing census, 2018 and sustainable development: The issues at stake. Journal of Techno Social, 11(1), pp. 16-28. https://publisher. uthm.edu.my/ojs/index.php/JTS/article/view/2715

Ochayi, C. (2021 June 3). Why no population census this year, NPC. Vanguard News. https://www.vanguardngr. com/ 
Ogunlade, M.U. (2000). Population and society. New York: Oxford University Press.

Reamer, A. (2018). Counting for dollars 2020: The role of the decennial census in the geographic distribution of federal funds. Initial Analysis, 16.

Sahara Reporters. (2020 December 8). Nigeria's population is now 206 million, NPC claims. http://saharareporters. $\mathrm{com} /$

Serra, G., \& Jerven, M. (2021). Contested numbers: Census controversies and the press in 1960s Nigeria. The Journal of African History, 62(2), 235-253.https://doi.org/10.1017/S0021853721000438

Stallings, W. (2006). Cryptography and network security, 4/E. Pearson Education India.

Stryker, S. (1981). Symbolic interactionism: Themes and variations in M Rosenberg and R Turner. Social psychology, New York: Basic Books.

Swan, J. E., \& Bowers, M. R. (1998). Services quality and satisfaction. Journal of services marketing, 12(1), 59-72. https://doi.org/10.1108/08876049810202375

Turner, J.H. \& Maryanski, A.R. (1988). Is "neofunctionalism" really functional? Sociological Theory, 6 (1), $110-121$.

United Nations, (2017). Principles and Recommendations for Population and Housing Censuses, Revision 3, Department of Economic and Social Affairs Statistics Division, New York, United States.

United Nations Economic Commission for Europe (UNECE). (2006). Conference of European statisticians' recommendations for the 2010 censuses of population and housing. Published by the United Nations Economic Commission for Europe in cooperation with the Statistical Office of the European Communities (Eurostat): Geneva, Switzerland.

\section{Correspondence:}

